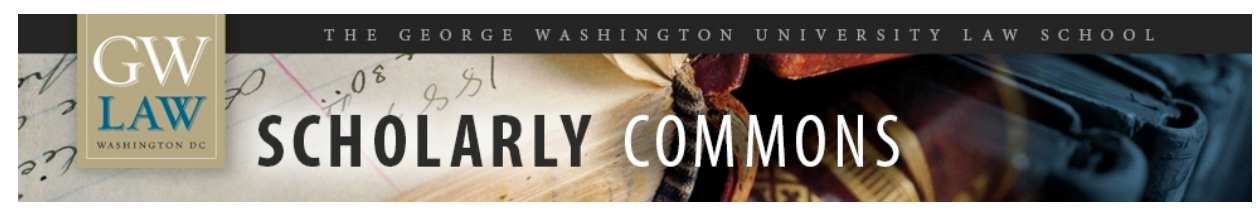

\title{
An Analysis of Pascal Lamy's Proposal on Collective Preferences
}

Steve Charnovitz

George Washington University Law School, scharnovitz@law.gwu.edu

Follow this and additional works at: https://scholarship.law.gwu.edu/faculty_publications

Part of the Law Commons

\section{Recommended Citation}

Charnovitz, Steve, "An Analysis of Pascal Lamy's Proposal on Collective Preferences" (2004). GW Law Faculty Publications \& Other Works. 406.

https://scholarship.law.gwu.edu/faculty_publications/406

This Article is brought to you for free and open access by the Faculty Scholarship at Scholarly Commons. It has been accepted for inclusion in GW Law Faculty Publications \& Other Works by an authorized administrator of Scholarly Commons. For more information, please contact spagel@law.gwu.edu. 


\title{
An Analysis of Pascal Lamy's Proposal on Collective Preferences
}

\author{
CSteve Charnovitz*
}

\begin{abstract}
In September 2004, then-European Commissioner for Trade Pascal Lamy released his study on the political challenge of 'collective preferences' for the world trading system. Lamy defines 'collective preferences' as 'the end result of choices made by human communities that apply to the community as a whole'. The adoption of collective preferences by governments can complicate international trade when a good or service from an exporting country is not acceptable in an importing country. Collective preferences cause a problem for the WTO if the resulting measure violates WTO rules and yet the measure is too popular in the regulating country for the government to withdraw it. The paradigmatic example is European Communities - Hormones in which the European Commission could not comply because of contrary popular and parliamentary opinion. To address cases like that, Lamy proposes the negotiation of a new safeguards provision in the WTO which would permit governments to retain strongly-supported measures provided that compensation is paid. The purpose of this article is to analyze Lamy's paper and to contribute to the continuing international debate on 'collective preferences'. The article concludes that while Lamy's proposal is a worthy idea, achieving it in the WTO is highly unlikely.
\end{abstract}




\section{INTRODUCTION}

In his final year as European Commissioner for Trade, Pascal Lamy initiated a study on the political challenge of 'collective preferences' for the world trading system. ${ }^{1}$ The project proved controversial and Lamy's ideas received considerable criticism. ${ }^{2}$ When the paper was completed in September 2004, it did not emerge with the imprimatur of the Commission. Nevertheless, the ideas in Lamy's thoughtful paper merit more attention.

Lamy defines 'collective preferences' as 'the end result of choices made by human communities that apply to the community as a whole'. ${ }^{3}$ The community might be a nation, a subnational unit, or an international unit. Over the centuries, he explains, socially-defined preferences have enable human progress and serve as markers of identity. Individual choices are synthesized through political debate via the governmental institutions inside the community.

Lamy contends that Europe has collective preferences for multilateralism, environmental protection, food safety, cultural diversity, public provision of education and health care, precaution in biotechnology, and welfare rights. Any such collective preference is 'not set in stone', Lamy

\footnotetext{
*George Washington University Law School, 2000 H Street, Washington, DC 20052. Email: scharnovitz@law.gwu.edu

This article is based on the author's presentation at the Conference

'Y-a-t-il limites sociales à l'ouverture des marchés?', sponsored by En Temps Réel, December 2004.

${ }^{1}$ Pascal Lamy, 'The Emergence of Collective Preferences in International Trade: Implications for Regulating Globalisation', 15 September 2004, http://trade-

info.cec.eu.int/doclib/docs/2004/september/tradoc_118925.pdf [hereinafter 'Lamy Paper'] (visited 19 December 2004).

${ }^{2}$ See, e.g., Guy de Jonquieres, 'Lamy Studies Radical Idea for Imports Veto', Financial Times, 6 February 2004, 9; (Editorial), 'Lamy's Big Idea', Financial Times, 10 February 2004, 14; 'EU "Collective Preferences" Concept Rings Alarm Bells in Washington', Food Chemical News, 12 April 2004, 25; 'UNICE Slams Lamy Over "Collective Preferences"', European Report, 1 May 2004.
}

${ }^{3}$ Lamy Paper, above $\mathrm{n} 1$, at 2 . The tension between individual human freedom and collectivism is not discussed in Lamy's Paper, or in this article. 
acknowledges, but rather evolves over time. ${ }^{4}$ He also points out that collective preferences 'are not always rational; they are forged by political experience' within a community. ${ }^{5}$

Outside the community, collective preferences may collide because "there is no legitimate higher authority, [and] no world government, to act as referee' and ensure that a global collective preference emerges. ${ }^{6}$ This governance gap complicates international trade. As Lamy explains, 'Traded goods and services are both an embodiment of and vehicle for the collective preferences of the countries producing them; they then become an interface with the collective preferences of the consumer country'? Although this phenomenon is not new, Lamy recognizes, he asserts that only recently has this value interface become a key feature of international trade. ${ }^{8}$ Lamy points to three factors promoting this development: (1) lower customs duties, (2) greater 'ideological content' of goods and services, and (3) greater awareness of citizens and consumers.

While Lamy doubts that globalization threatens collective preferences, he points out that incompatibility problems may arise. Lamy views the WTO disputes on hormones, shrimp-turtle, and asbestos as disputes about collective preferences, and predicts that there will be more of such disputes. He expresses concern that globalization and the World Trade Organization (WTO) may be rejected by a public opinion that sees international trade and WTO rules as a threat to nationallychosen collective preferences. The 'sudden emergence' and 'new difficulty' of collective preferences brings to light the need for governments to respond. ${ }^{9}$

${ }^{4}$ Ibid.

${ }^{5}$ Ibid.

${ }^{6}$ Ibid.

${ }^{7}$ Ibid, at 3 .

${ }^{8}$ Ibid.

${ }^{9} \mathrm{Ibid}$, at $5,7$. 
The response Lamy proposes is for the WTO to defer to national collective preferences. In particular, he urges formal guarantees that have a legal and a 'symbolic significance'. ${ }^{10}$ With regard to future trade liberalization, Lamy suggests that 'it is advisable not to push for integration in areas rich in collective preferences'. ${ }^{11}$ With regard to future WTO rules, Lamy points to the possibility of introducing an additional safeguard provision.

Such a safeguard would function as an 'insurance policy' to give a guarantee that trade integration will not intrude on legitimate collective preferences or be a threat to social choices. ${ }^{12}$ In order to be justified in invoking this clause, a government would have to demonstrate a coherent underlying social demand in its country and that the measure being challenged is consistent with that demand. The government would also have to demonstrate that the measure does not restrict trade more than other measures capable of satisfying the social demand. Lamy's paper implies that collective preferences to be acknowledged cannot include protectionism. Thus, a plain tariff would not be an eligible measure for the collective preference safeguard.

Lamy distinguishes his proposal for a new safeguard clause from the existing WTO Agreement on Safeguards. One difference is that a government invoking the new safeguard would have to provide immediate compensation. ${ }^{13}$ Lamy suggests that compensation could be a payment to affected exporters in other countries, or, in the case of harm to developing countries, could be the

\footnotetext{
${ }^{10}$ Ibid, at 8.

${ }^{11}$ Ibid, at 9 .

${ }^{12}$ Ibid, at 10 .

${ }^{13}$ Under the WTO Agreement on Safeguards, a Member invoking a safeguard is required only to 'endeavour' to maintain a substantially equivalent level of concessions. Uruguay Round Agreement on Safeguards, Article. 8.1. The Members concerned may agree on any adequate means of 'trade compensation for the adverse effects of the measure on their trade'. In the absence of suitable trade compensation, the affected exporting Members may engage in self-help to retaliate. Ibid Article 8.2 This right to retaliate may not be exercised for the first three years of the safeguard provided that the safeguard conforms to the Agreement and that there has been an absolute increase in imports. Ibid Article 8.3.
} 
provision of trade-related technical assistance. Lamy favors the principle of compensation because a country making social choices has a 'responsibility to bear the external cost of those measures' ${ }^{14}$

Another difference from the current WTO safeguard is that a country wishing to use the new escape clause would have to conduct an internal review of the collective preference in order to find out whether it is well-founded. This review would entail widespread consultation and further research. If the preference is 'unwarranted', there should be a effort to educate people with a view to changing their preferences. ${ }^{15}$

Lamy's paper is rich in nuance and thus hard to capsulate. Still, this brief summary can serve as a basis for an analysis of the ideas in Lamy's paper.

The purpose of this article is to contribute to the international debate on 'collective preferences,' and to offer some specific comments on Lamy's paper and its proposal for a collective preference safeguard. The article proceeds in six parts: Part I discusses the significance of the collective preference problem and takes note of some proposals that predate Lamy's paper. Part II examines the many challenges in validating a collective preference. Part III considers whether Lamy's proposal truly would add anything new to the WTO and concludes that it would. Part IV discusses the distinction between inwardly-directed and outwardly-directed preferences and their different dynamics. Part V posits that whether a new safeguard is needed depends to some extent on whether the interpretation of existing WTO provides sufficient leeway for diverse and legitimate domestic measures. Part VI concludes.

\section{THE SIGNIFICANCE OF THE COLLECTIVE PREFERENCE PROBLEM}

The problem Lamy addresses is real. Countries will often adopt different public policies, and, as Lamy says, trade becomes as a 'natural point of intersection for different systems of collective

\footnotetext{
${ }^{14}$ Above $\mathrm{n} 1$, at 11 .

${ }^{15}$ Ibid.
} 
preferences ${ }^{16}$ Clashing or distinctive collective preferences between governments have led to trade disputes (e.g., hormones), and will assuredly do so in the future. When WTO rules inhibit domestic autonomy, that can undermine public support for the trading system. ${ }^{17}$

As I read Lamy's paper, he makes a distinction between the desire to insulate a domestic market from foreign competition and the protection of particular social values. Lamy is not seeking to provide more opportunities for mercantilism or autarky. Rather, he is implicitly distinguishing between wealth-generation values of a society and other social values like environmental quality, cultural diversity, or social equity. Lamy wants to preserve opportunities for values of the second sort.

Although Lamy's paper has been criticized for being protectionist, or unintentionally opening the door to protectionism, such criticisms are poorly aimed. Protection does not need to insinuate its way into the trading system. It is already legally present in the WTO rules that permit (or encourage) tariffs, anti-dumping duties, special and differential treatment, China-specific safeguards, etc. Those who want to oppose protectionism should focus on those pervasive practices inside the system, rather than cavil at Lamy's efforts to enable the WTO to better accommodate democracy. Lamy's proposal should be evaluated on its own terms, not dismissed simply because it may inhibit specific crossborder transactions. After all, the rationale for Lamy's project is to maintain the political consensus in favor of the trade-liberalizing function of the WTO.

That said, one might speculate on what a new safeguard rule would mean for global economic efficiency. Assume that Country A has a collective preference that has been ruled a WTO violation (e.g., a hormone ban), and the government of A decides to keep the measure anyway. Under current

\footnotetext{
${ }^{16}$ Ibid, at 3.

${ }^{17}$ See Marco C.E.J. Bronckers, 'Better Rules for a New Millennium: A Warning Against Undemocratic Developments in the WTO', 2 JIEL 547 (1999); Bruce Stokes, 'New Trade Barriers: National Preferences', National Journal, 24 April 2004, 1276. A government with a WTO-illegal collective preference might be able to secure a waiver from the WTO Ministerial Conference.
} 
WTO practice, the complaining country will be authorized to impose prohibitive tariffs on A. Such a trade cutoff lowers economic efficiency. This reduction would not happen if A compensates the complaining country by granting it more trade access or by paying cash.

The calculation gets complicated, however, because one also has to consider the impact of the new rule on the adoption of new collective preference measures by A. If trade sanctions against it can now be avoided, then A may be more likely to gratify collective preferences, and that may lead to reductions in trade and efficiency. After all, the cost of compensation will not be borne directly by those in A who champion a preference. So the overall effect of a new safeguard on efficiency is indeterminate in the abstract.

Although collective preferences are a challenge for the trading system, they are hardly the new problem portrayed in Lamy's paper. It may be true that collective preference clashes have a greater saliency now than they did 20 or 100 years ago. Still, the challenge of social policies embedded in traded goods is hardly new. ${ }^{18}$ It was the need to provide space for national policies that led to the negotiations in 1927 regarding the exceptions that would be introduced into the International Convention for the Abolition of Import and Export Prohibitions and Restrictions. ${ }^{19}$ That Convention's provision for policy exceptions served as the model for Article XX of the General Agreement on Tariffs and Trade (GATT). In characterizing the collective preferences debate as a contemporary phenomenon, Lamy's paper may give the reader the mistaken impression that GATT and WTO law was not written to accommodate collective preferences. This neglect of history leads to a distortion in Lamy's analysis because he does not consider the extent to which a more flexible

\footnotetext{
${ }^{18}$ See Josef Grunzel, Economic Protectionism (Oxford: Clarendon Press 1916) 192-99 (discussing 'Protection by Concerted Popular Action').

${ }^{19}$ International Convention for the Abolition of Import and Export Prohibitions and Restrictions, done at Geneva, 8 November 1927, 46 U.S. Statutes at Large 2461, arts. 4, 5 (not in force).
} 
interpretation of the trade law general exceptions ${ }^{20}$ could produce a solution to the WTO legitimacy problems he is addressing. Indeed, in two of the examples that he points to (shrimp-turtle and asbestos), the GATT exceptions did provide space for the national preference being challenged.

That Lamy has overlooked some of the important literature is also noticeable in his discussion of the 'interface' function. John H. Jackson presented the interface concept in his 1989 book The World Trading System. ${ }^{21}$ Alongside an exposition of the basics of the traditional GATT safeguard, Jackson noted that 'In a world of increasing economic interdependence, there may be additional arguments which support safeguard programs' ${ }^{22}$ The situation Jackson was addressing at the time was the need to allow 'independent choice of economic systems for societies' and to 'prevent too much pressure for change of the domestic economic structure resulting from increased international trade originating in economies which are structured differently' ${ }^{23}$ The collective preferences considered by Jackson in 1989 are perhaps more structural than the ones being considered by Lamy today. Yet both boil down to the clash of national values and ideologies played out in the trading arena.

\footnotetext{
${ }^{20}$ See General Agreement on Tariffs and Trade 1994 (GATT), Articles XX, XXI; General Agreement on Trade in Services (GATS), arts. XIV, XIV bis, Uruguay Round Agreement on Trade-Related Aspects of Intellectual Property Rights (TRIPS Agreement), Articles 13, 17, 30, 73. All of these exceptions in my view concern collective preferences. Several major World Trade Organization (WTO) agreements overseeing domestic policy do not contain general exceptions-namely, the Uruguay Round Agreement on the Application of Sanitary and Phytosanitary Measures (SPS Agreement), the Uruguay Round Agreement on Technical Barriers to Trade (TBT Agreement), the Uruguay Round Agreement on Agriculture, and the Uruguay Round Agreement on Subsidies and Countervailing Measures (SCM Agreement).

${ }^{21}$ John H. Jackson, The World Trading System (Cambridge: MIT Press 1992). Jackson's attention to the 'interface' problem goes back at least as early as 1978. Ibid, at 378.

${ }^{22} \mathrm{Ibid}, 218,305$.

${ }^{23}$ Ibid, at $152-53$.
} 
Other analysts have also suggested the need to expand the availability of a safeguard for national policies. In 1996, Dani Rodrik proposed a 'social-safeguards' clause for labor standards. ${ }^{24}$ According to Rodrik, it is 'axiomatic that no nation has to maintain free trade with a country or in a specific product if doing so would require violating a widely held ethical standard or social preference at home'. ${ }^{25}$ In 2001, the team of Nicholas Perdikis, William A. Kerr, and Jill E. Hobbs suggested the negotiation of a WTO Agreement on Trade Related Aspects of Consumer Concerns that would separate producer-based trade restrictions from consumer-based trade restrictions. ${ }^{26}$ The Agreement could permit governments to impose trade barriers based on consumer concerns, subject to paying compensation set through compulsory arbitration. To assist governments in evaluating the existence and intensity of consumer concerns, the authors called for an international Commission on Consumer Issues and Trade. In 2004, Jagdish Bhagwati suggested that the WTO could show more flexibility when the Appellate Body 'finds against legislative or executive actions that are virtually dictated by public opinion'. ${ }^{27}$ In Bhagwati's proposal, the government implicated would 'make a tort payment to the injured industry' based on the profits lost by the exporters. ${ }^{28}$ Lamy's paper fails to mention any of these earlier proposals.

\footnotetext{
${ }^{24}$ Dani Rodrik, 'Labor Standards in International Trade: Do They Matter and What Do We Do About Them?', in Robert Z. Lawrence, Dani Rodrik and John Whalley, Emerging Agenda for Global Trade: High Stakes for Developing Countries (Washington: Overseas Development Council 1996) 35, 62. Rodrik introduced the idea in 1995.

${ }^{25}$ Rodrik, above n 24, at 63 (emphasis deleted).

${ }^{26}$ Nicholas Perdikis, William A. Kerr and Jill E. Hobbs, 'Reforming the WTO to Defuse Potential Trade Conflicts in Genetically Modified Goods', 24 The World Economy 379 (2001), at 394-97.

${ }^{27}$ Jagdish Bhagwati, In Defense of Globalization (New York: Oxford University Press 2004) 152. ${ }^{28}$ Ibid.
} 


\section{VALIDATING COLLECTIVE PREFERENCES}

One of the most interesting parts of Lamy's paper is his discussion of the identification and validation of collective preferences. Two dialogic processes are noted. First, a government wishing to use the new WTO safeguard would have to conduct an internal review of the collective preference. Although Lamy's paper is sketchy, he seems to be saying that the government would instigate a reassessment of the collective preference to see whether it is a 'genuine' social expression and to see whether it is warranted. ${ }^{29}$ If found to be 'unwarranted', then there would be an effort to educate people with a view to changing their preferences. ${ }^{30}$ The second process is that a government would have to demonstrate to the WTO the genuineness of its collective preference by showing a coherent underlying social demand. Lamy does not elaborate the details of either process.

The implicit but unexamined assumption in Lamy's paper is that a popularly-supported policy has more international valence than a policy dictated by fiat. In other words, Lamy seems to be saying that the WTO should show greater respect for broad and intense public opinion than for policies chosen through bureaucratic expertise, judicial authority, or political representation.

As applied to the WTO, this is a revolutionary concept. The self-perception of the WTO is an organization comprised of impermeable 'Members'. At home, the members might be democratic states (like France), non-democratic state (like Cuba), or non-state customs territories (like Taiwan). Yet inside the WTO, membership is homologous and those three categories have no relevance. As a consequence, no WTO rule or status is linked to the support of public opinion within a country. ${ }^{31}$

\footnotetext{
${ }^{29}$ Above n 1, at 8 .

${ }^{30}$ Ibid, at 11.

${ }^{31}$ The closest one gets is Article 3.1 of the Uruguay Round Agreement on Safeguards, which calls for a 'public hearing' in which interested parties can present their views on whether a safeguard would be in the public interest. See also Uruguay Round Agreement on Implementation of Article VI of the General Agreement and Tariffs and Trade 1994 (Anti-Dumping Agreement), Articles 5.1, 5.4 (requiring the initiation of antidumping investigation when proposed on behalf of the domestic industry, with no status provided for contrary public opinion).
} 
Lamy does not explain why this member-centrism should be uprooted. The paradigm of WTO decisionmaking is that governments speak for their citizens and that the WTO does not look inside the veil of the individual Member. ${ }^{32}$ For example, the WTO does not require Members to demonstrate parliamentary approval for joining the WTO or amending its agreements. ${ }^{33}$

Consequently, Lamy is making a revolutionary suggestion in saying that whether a collective preference should qualify for a safeguard depends on the objective existence of an underlying social demand. Under existing practice across all WTO agreements, a government's mere assertion of a position would be sufficient at the WTO even if the position completely fails to reflect popular will within that country. ${ }^{34}$

Lamy's paper elides this normative issue as well as the practical problems the WTO faces in validating a collective preference. Such validation will be difficult enough for the European Union or the United States, but how is it to be done for China or Cuba? Moreover, if citizen support is to be a precondition for a collective preference safeguard, then perhaps it should also be a precondition for a

\footnotetext{
${ }^{32} \mathrm{~A}$ few marginal exceptions exist: One area where the veil has been pierced are the arbitral awards under Article 21.3 of the Uruguay Round Understanding on Rules and Procedures Governing the Settlement of Disputes (DSU). That provision provides for setting the 'reasonable period of time' for implementation. A norm that has developed is that implementation requiring a legislative change is likely to get more time than implementation needing only an administrative change. See Pierre Monnier, 'The Time to Comply with an Adverse WTO Ruling', 35(5) Journal of World Trade 825 (2001). Some veil piercing can also be seen in GATT Article XXVIII bis 3(a) (individual industries).

${ }^{33}$ See Marrakesh Agreement Establishing the World Trade Organization, Article X:1 (expressing no requirement for parliamentary approval of a Member's acceptance of WTO amendment). But see WTO Secretariat, 'The WTO ... In Brief', http://www.wto.org/english/thewto_e/whatis_e/inbrief_e/inbr00_e.htm (visited 19 December 2004) ('Virtually all decisions in the WTO are taken by consensus among all member countries and they are ratified by members' parliaments'.).

${ }^{34}$ See WTO Secretariat, 'WTO Policy Issues for Parliamentarians', at 13, http://www.wto.org/english/thewto_e/whatis_e/whatis_e.htm (visited 19 December 2004) ('If the claim that 'governments do not represent the interests of citizens' were true, then it is something that citizens need to correct at home. It is not something that an inter-governmental body like WTO can deal with'.).
} 
regular safeguard in the WTO. ${ }^{35}$ On what basis should the WTO inquire about citizen preferences on some issues if not on all issues? Another practical problem in discovering public preferences is what to do about untoward government influence in shaping those preferences. This concern was identified by the European Communities - Trade Description of Sardines panel in its comment on 'self-justifying' regulatory trade barriers. ${ }^{36}$ If government action has helped to create irrational yet strongly-held consumer preferences, should such preferences qualify for the new safeguard? Lamy does not address these difficult questions.

Lamy does not present details on how a WTO Member would show that a contested preference is based on an underlying social demand rather than on special-interest politics. Polling is one possibility; holding a referendum is another. If polling is used, it will be important to formulate the question carefully. Consider two possible policy questions on hormones: Question \#1 is: 'Do you want to keep the ban on hormones in imported meat even though the WTO has ruled that it violates trade rules?'. Question \#2 is: 'Do you want to keep the ban on hormones in imported meat recognizing that under WTO rules, the United States gets to exact $\$ 117$ million of benefits from Europe each year?'. The second question is better because it attaches a cost to the preference.

Lamy's suggestions for in-country validation are less problematic. He maintains that a collective preference safeguard would lead to better dialogue within a polity as the government

\footnotetext{
${ }^{35}$ The Agreement on Safeguards, Article 3.1, requires governments to entertain comments from interested parties regarding whether the safeguard would be 'in the public interest'. No WTO caselaw has suggested that a panel can second-guess whether a government properly decided whether a safeguard was in the public interest. In general, WTO rules do not require a government to take into account the costs of its own trade measure to its own economy. In United States - Gasoline, the Appellate Body held that the U.S. regulation violated the WTO because, inter alia, the U.S. government had not taken into account the cost of its regulation on foreign producers. WTO Appellate Body Report, United States - Standards for Reformulated and Conventional Gasoline, WT/DS2/AB/R, adopted 20 May 1996, at 28. No parallel jurisprudence requires governments to take into account homeland costs.

${ }^{36}$ See WTO Panel Report, European Communities - Trade Description of Sardines, WT/DS231/R, adopted as modified by the Appellate Body 23 October 2002, para. 7.127 (discussing the danger that WTO Members could shape consumer expectations through regulatory intervention).
} 
engages in deliberation with the public about a particular collective preference. ${ }^{37}$ Lamy does not give an example. In my view, European Communities - EC Measures Concerning Meat and Meat Products (Hormones) ${ }^{38}$ is an instance where a discursive process for clarifying social choice could have been useful in encouraging the public to reconsider the scientific evidence, or lack therefore, underlying the hormone ban. My impression is that the WTO's rejection of the Commission's defense did not trigger any dialectic reconsideration within Europe as to the wisdom of the hormones ban. If Lamy's new safeguard would promote a robust national dialogue, that could be a constructive contribution.

Rodrik's 1996 proposal is more detailed regarding validation at the national level. Rodrik suggests that individuals seeking a social safeguard would petition their government and then the government would hold a public hearing where all sides would express their views. ${ }^{39}$ Following the hearing, the administrative agency would decide whether the claim for the safeguard has broad-based public support. Rodrik would require testimony from groups whose material interests would be adversely affected by the requested trade restriction. Unless such groups support the safeguard, it would not be imposed.

Although Lamy's paper focuses on internal policy review within the country seeking to exercise a defensive safeguard, one can also imagine the value of public discussion in the country lodging a WTO complaint. For example, one wonders if Canada's loss in European Communities Measures Affecting Asbestos and Asbestos-Containing Products led to any social dialogue within

\footnotetext{
${ }^{37}$ The importance of promoting deliberation was noted by Jan Tumlir in his Wincott Memorial Lecture in 1984. Jan Tumlir, Economic Policy as a Constitutional Problem (London: Institute of Economic Affairs 1984) 12-13.

${ }^{38}$ WT/DS26,48, adopted 13 February 1998. The case is discussed in Reinhard Quick and Andreas Blüthner, 'Has the Appellate Body Erred? An Appraisal and Criticism of the Ruling in the WTO Hormones Case’, 2 JIEL 603 (1999).

${ }^{39}$ Rodrik, above n 24, at 63-65.
} 
Canada about the practice of using or exporting asbestos. My impression is that it did not. There could also be benefit in stimulating a public discussion before a government commences litigation in the WTO. In the hormones dispute, I do not know if U.S. public opinion would have supported lodging the case.

Social dialogue may also be of value in a defendant country losing a WTO case. This could occur if a special interest provision is found to be WTO-illegal and public opinion get aroused in favor of repeal. At present, there is no connection between the surveillance carried out by the WTO Dispute Settlement Body (DSB) ${ }^{40}$ and the domestic process for coming into compliance. By improving the transparency of the DSB, the WTO could tap into the power of public opinion. The greater ensuing public awareness might promote compliance.

\section{THE VALUE-ADDED OF A NEW SAFEGUARD}

Lamy presents his proposal as a new initiative for the WTO, and yet it is worth asking what is new. The European Communities - Hormones case shows that a WTO Member enjoying a collective preference can keep it, notwithstanding the WTO ruling against it. Furthermore, if the Community chose to compensate the countries affected by its hormone ban, it could settle the complaints against it in full conformity to the rules of the WTO. ${ }^{41}$ So what exactly does the Lamy plan add? Answering this question requires a discussion of the WTO rules on compensation and compliance.

\section{A. Compensation}

Although compensation can occur now, it often does not because trade compensation has to be performed on a most-favoured-nation $(\mathrm{MFN})$ basis. $^{42}$ In other words, any trade concession granted to a complaining party would also have to be granted to all other WTO Members. This MFN rule

\footnotetext{
${ }^{40}$ DSU Article 21.6.

${ }^{41}$ See DSU Articles 3.3, 3.6, 3.7, 22.8 (settlement), 3.7, 22.1 (compensation).

${ }^{42}$ See DSU Article 22.1, GATT Article I.
} 
makes the direct cost of compensation high. Furthermore, the cost of compensation snowballs when one considers the need to tailor it to every affected country and the buildup of transaction costs in negotiating such compensation. Take hormones as an example. Perhaps Europe could have negotiated trade concessions for the two complaining countries, the United States and Canada. But once compensation is promised, other countries can threaten to bring the same WTO case and would have to be compensated with trade concessions that would be different from the ones particularized for the United States and Canada. Each compensation package would then have to be granted unconditionally to other WTO Members. This gets expensive on a mercantilist metric, and explains why negotiated compensation will often fail. Instead the default-'suspension of concessions or other obligations ${ }^{43}$ by the complaining countries - will tend to be used because the defendant country can avoid liberalizing on an MFN basis and accruing the transactions costs for negotiating that liberalization.

Whether Lamy's plan cuts this Gordian knot is unclear. To the extent that Lamy relies on traditional trade compensation, the same practical difficulties arise. But Lamy has a different plan. He suggests that the compensation go directly to 'affected exporters' and 'take the form of payment of a pre-set amount'. ${ }^{44}$ Compensation of this sort seems not to have been contemplated by the drafters of the Uruguay Round agreements. Financial compensation to private economic actors is an innovative approach that may avoid the way in which MFN leads to overcompensation. ${ }^{45}$ All victim countries would still have to be paid off, but only once. Yet while the direct cost of compensation

\footnotetext{
${ }^{43}$ DSU Article 22.7.

${ }^{44}$ Above n 1 , at 11.

${ }^{45} \mathrm{MFN}$ leads to overcompensation because the compensation tailored for Country A is enjoyed by B, $\mathrm{C}$, etc. and the compensation tailored for B is enjoyed by A, C, etc. Thus, B and C get overcompensated.
} 
might be less expensive ${ }^{46}$ under Lamy's plan (as compared to the DSU), Lamy may not have a solution to the problem of transaction costs. ${ }^{47}$ Lamy's paper does not discuss how the amount of compensation is to be determined. ${ }^{48}$ As the Perdikis, Kerr, and Hobbs study notes, international arbitration could be used. Taking hormones as an example, one could imagine an arbitrator determining how much the affected U.S. meat exporters should be recompensed by the European Commission. Granting compensation directly to victims is better than passing it down through a government. ${ }^{49}$ The proposition that WTO Members are ready to endorse state responsibility to individuals is dubious however. ${ }^{50}$

Lamy is not ready to go all the way for developing countries. Even though affected exporters in developed countries are to receive payments, exporters in developing countries apparently are not. For developing countries, Lamy prescribes 'complementary policies' such as trade-related technical

\footnotetext{
${ }^{46}$ The 'budget cost' of Lamy's plan would be more expensive.

${ }^{47}$ Lamy says that compensation is to be 'pre-set'. Above n 1, at 11 . I cannot imagine a workable formula.

${ }^{48}$ Lamy suggests that exporters are only to be 'partially' compensated, but does not explain why compensation should be less than 100 cents on the Euro. Ibid.

${ }^{49}$ See 'Bhopal: The World's Worst Industrial Disaster; Victims Still Wait for Compensation', The Record (Kitchener-Waterloo), 3 December 2004, A1 (discussing the slow distribution of funds from Union Carbide settlement with Indian government in 1989).

${ }^{50}$ The closest the WTO has gotten is United States - Copyright Act, where the DSU Article 25 arbitrator estimated the amount of royalties that were not being paid to European right holders because of the U.S. measure. Award of the Arbitrators, United States - Section 110(5) of the US Copyright Act, WT/DS160/ARB25/1, circulated 9 November 2001. This award of $€ 1.2$ million became the basis for a temporary settlement in which the U.S. government deposited three years worth of compensation into a special fund that is used to support and promote European musical artists. The monies did not go to the victims however. Instead, the funds are administered by the European Grouping of Societies of Authors and Composers which is spending the funds to combat piracy on the internet and to support copyrights. See http://www.gesac.org/eng/news (visited 19 December 2004).
} 
assistance or capacity building. ${ }^{51}$ Lamy does not explain why developed country exporters are to be given more favorable treatment than developing country exporters.

Perhaps the reason is a presumption by Lamy that the injured exporters in the developed countries are not doing anything wrong while the exporters in developing countries probably are and so it would be unjust to compensate them directly. To take an example, the exporters in Myanmar using forced labor do not deserve compensation, while the exporters in the United States using hormones do because hormone use is not known to be unsafe. Whether or not this example ${ }^{52}$ is convincing to the reader, it may demonstrate that the conditions justifying compensation are not found only in developed countries.

In Rodrik's social safeguard proposal, compensation would be required for democratic countries but not authoritarian ones. ${ }^{53}$ The logic is that when Country A enforces its collective preference against Country B, if B is democratic, then the conditions in B reflect the persisting collective preferences of B's electorate. So A should acknowledge the conflict in preferences by compensating B. Rodrik has offered a normatively appealing bright-line rule, but its workability depends on being able to determine which countries are democratic.

The puzzle of who should get compensated is accompanied by the puzzle of why compensation should occur. Notions of 'international fairness and responsibility' justify compensation, according to Lamy's paper. He explains that 'our trading partners pay a heavy price

\footnotetext{
${ }^{51}$ Above n 1, at 11.

${ }^{52}$ Bhagwati offers the example of compensating producers of factory-farmed chickens. He says that 'the payment is likely to be regarded as paying sinners for not practicing vices!'. Bhagwati, above note 27 , at 152 .
}

${ }^{53}$ Above n 24, at 66-67. 
for some of our domestic choices'. ${ }^{4}$ This gives the countries pursuing a collective preference the 'responsibility to bear the external cost of those measures'. 55

This argument seems to imply that the rationale for the compensation is the transborder financial harm rather than the WTO-illegality of the collective preference. That would be a farreaching justification for compensation because it would also apply to commercial policies such as tariffs and quotas. If the European Community has a low import quota for meat, it is exacting a 'heavy price' on foreign producers just as much as when the Community has a ban on hormones. Lamy presumably is not suggesting that governments using tariffs or employing trade remedies have a responsibility to compensate the frustrated foreign exporters. Nor is he suggesting that measures ostensibly taken for national security (and thus exempt from many WTO rules) should trigger compensation. So his argument for compensation, even though clothed as a justice claim, would seem to hark back to the nature and exceptionality of the safeguard and its presumptive inconsistency with current WTO rules.

In my view, compensation can serve two objectives. First, Country A compensates Country B because A's treatment of B violates WTO rules. Second, the compensation by A signals to Countries $\mathrm{B}, \mathrm{C}, \mathrm{D}$, etc. that $\mathrm{A}$ is not acting in a self-interested way. In other words, A's act to compensate shows the world that its safeguard is for altruistic reasons not commercial ones.

Another issue that Lamy does not discuss is the difficulty that lower-income countries would face in providing financial compensation. If Countries A and B both inhibit the same dollar value of trade with Country C, then both countries would owe C's exporters a commensurate amount of compensation. But if $\mathrm{A}$ is a high-income country and $\mathrm{B}$ is a low-income country, then $\mathrm{B}$ may be less able to pay the compensation, and thus less able to keep the collective preference.

\footnotetext{
${ }^{54}$ Above n 1 , at 11 .

${ }^{55}$ Ibid.
} 


\section{B. Legitimizing Preferences}

Lamy contends that his proposed safeguard clause is the "ultimate guarantee that trade integration will not pose a threat to legitimate collective preferences' ${ }^{56}$ Furthermore, he states that 'The outcome of conflicts involving collective preferences would be much the same as today but the existence of a safety net like a safeguard clause would enable the parties concerned to achieve that outcome without generating so much tension and friction, ${ }^{57}$ The avoidance of the tension and friction would come, presumably, because the safeguard would legitimize the continuation of the contested trade measure notwithstanding WTO rules. In other words, WTO members could keep their community preferences so long as they were willing to pay for them through compensation.

Given that description of Lamy's plan, the question arises whether it amounts to any real difference from current WTO law. After all, the WTO does not really 'strike down' national laws, even though commentators sometimes say that. ${ }^{58}$ A WTO Member can refuse to lift a trade barrier ruled to be a WTO violation as Europe did in the hormones dispute and the United States did in the Byrd Amendment dispute. Everyone would agree that ultimately, achieving compliance is up to the government found to be in violation.

Where there is a disagreement is whether WTO rules give the defending government a formal obligation to comply or merely an obligation to accept retaliation should it not comply. John $\mathrm{H}$. Jackson has championed the notion that governments do have an obligation to comply. ${ }^{59}$ Warren F.

\footnotetext{
${ }^{56}$ Ibid, at 10 .

${ }^{57}$ Ibid.

${ }^{58}$ See, e.g., Timothy M. Reif and Julie Eckert, 'Courage You Can't Understand: How to Achieve the Right Balance between Shaping and Policing Commerce before the World Trade Organization', 42 Columbia Journal of Transnational Law 657 (2004), at 710-11 (suggesting that panels and the Appellate Body 'strike down' national regulations).

${ }^{59}$ John H. Jackson, 'The WTO Dispute Settlement Understanding-Misunderstanding on the Nature of Legal Obligation' 90 AJIL 60 (1997); Jackson, 'International Law Status of WTO Dispute Settlement Reports: Obligation to Comply or Option to "Buy Out”?', 98 AJIL 109 (2004).
} 
Schwartz and Alan O. Sykes have ably argued that non-compliance may be an acceptable outcome. ${ }^{60}$ I have sided with Jackson in this debate. ${ }^{61}$

If one accepts that governments have an obligation to comply with WTO panel rulings against them, then Lamy's proposal does add something of value. The new safeguard would re-legitimize an otherwise WTO-illegal act based on a genuine collective preference. Right now, the European Union is a scofflaw in the WTO because it has not complied with the European Communities - Hormones ruling. ${ }^{62}$ This disconnect between the Community’s legal responsibility and its internal political capacity to make the required change has proved embarrassing. The new safeguard would provide an escape clause for governments in such circumstances.

The other major innovation is to enable the government with the WTO-illegal collective preference to buy its way out rather than to suffer a 'suspension of concessions or other obligations' ('SCOO') selected by the complaining party. Agreed trade compensation will continue to be possible under Lamy's proposal as it is now. But Lamy's plan adds an additional option not plainly available now of paying non-trade compensation.

\section{WHAT TO DO ABOUT OUTWARDLY-DIRECTED PREFERENCES}

Lamy's paper does not discuss whether there are to be limits to the range of permissible preferences.

Two types of preferences are at stake-(1) inwardly-directed preferences, for example, regarding

\footnotetext{
${ }^{60}$ Warren F. Schwartz and Alan O. Sykes, 'The Economic Structure of Renegotiation and Dispute Resolution in the World Trade Organization', 31 Journal of Legal Studies S179 (2002).

${ }^{61}$ Steve Charnovitz, 'Recent Developments and Scholarship on WTO Enforcement Remedies', in Julio Lacarte and Jaime Granados (eds), Inter-Governmental Trade Dispute Settlement: Multilateral and Regional Approaches (London: Cameron May 2004) 151, 161.

${ }^{62}$ In late 2004, the European Commission announced that Europe was now in compliance with the European Communities - Hormones decision. Chris Clayton, 'EU Assails Continuing Sanctions', Omaha World-Herald, 9 November 2004, 3D. Rather than seek a compliance ruling under DSU Article 21.5, however, the Commission is requesting an original panel to consider the lawfulness of continued U.S. retaliation. The non-use of Article 21.5 would seem to be a tactic to secure a new panel in order to avoid being judged by members of the original panel.
} 
food wholesomeness, and (2) outwardly-directed preferences, for example, to preserve tropical forests in other countries. ${ }^{63}$ The paper discusses both types, so presumably Lamy is not making a distinction between them. Among the outwardly-directed preferences he discusses are turtle protection, death penalty, forced labor, and child labor. He also states that 'Most of the difficulties with collective preferences arise when countries think that their choices should apply to everyone, not just to them'. ${ }^{64}$

In my view, the dichotomy between inwardly and outwardly-directed preferences is important. This distinction is not an question of 'processes and production methods" ${ }^{65}$ because PPMs are used for both inward and outward preferences. ${ }^{66}$ Rather, the dichotomy hinges on the purpose of the contested governmental measure. Food safety measures like Europe's hormone ban may set standards for practices in the United States, but the ostensible purpose of the measure is to protect the health of European consumers. The distinction gets murky, however, because any outwardly-directed measure will have been stimulated by the volitions of individuals inside the regulating country. For example, the United States law banning imports of dog and cat fur products ${ }^{67}$ is outwardly-directed, but the law also satisfies a demand inside the United States for taking this action. Nevertheless, there is a difference between the two types of preferences, particularly in their interface dynamics.

The outwardly-directed measure is more problematic because of the potential clash in the collective preferences chosen by importing and exporting countries. The people of the United States

\footnotetext{
${ }^{63}$ See Carlos Manuel Vázquez, 'Trade Sanctions and Human Rights - Past, Present, and Future', 6 JIEL 797 (2003), at 812-19 (discussing inwardly and outwardly directed measures).

${ }^{64}$ Above n 1, at 12.

${ }^{65}$ See SPS Agreement, Annex A, para. 1.

${ }^{66}$ For example, PPMs are used for food safety. See Gregory L. White and Roger Thurow, 'In Global Food-Trade Skirmish, Safety is the Weapon of Choice', Wall Street Journal, 15 December 2004, A1.

${ }^{67} 19$ U.S.C.S. $§ 1308$ (2004). The law states that the trade of dog and cat fur products is ethically and aesthetically abhorrent to United States citizens.
} 
may have a collective preference for preventing the slaughter of dogs and cats for fur, but the people of China (for example) may have a preference for engaging in such slaughter. This is not a conflict of law because the United States is not trying to make pet slaughter unlawful in China. Rather, it is a clash of collective preferences. Trade in dog and cat fur is being stymied by the collective preferences in the United States failing to match the collective preferences in China. ${ }^{68}$ If the U.S. ban is ever ruled WTO-illegal, Lamy's safeguard would allow the United States to keep the ban so long as it compensates the producers in China. (One wonders though whether U.S. public opinion would tolerate using U.S. taxes to pay off Chinese animal skinners any more than U.S. public opinion would tolerate repealing the law.)

The dog fur example shows the complexity of the interface possibilities. For an inwardlydirected preference like meat produced without injected hormones, the clash between preferences is limited because European consumers can enjoy non-hormone meat and the U.S. consumers can enjoy the hormone meat. The trade dispute can be worked if U.S. producers ship non-hormone meat to Europe or if Europe compensates the United States. ${ }^{69}$ For an outwardly-directed preference like a ban on fur trade, there is a greater clash in preferences because if the U.S. ban does not prevent the animal slaughter, then the United States cannot achieve that objective in China. The only benefit from the U.S. ban would be to prevent U.S. moral complicity. For other outwardly-directed preferences, the interface will be much harder because it will not be possible for both sides to continue to enjoy their preferences. These are the challenges where international collective action is needed. Take climate change, for example, where Europe has a greater collective preference for taking action than does the

\footnotetext{
${ }^{68}$ The fact that China produces and exports such fur shows that China has a preference of some sort for the dog and cat killing. See Sarah Chalmers, 'The Sickening Trade in Dogs, Slaughtered by the Hundred to be Made into Fashion Accessories for the West', Daily Mail (London), 29 May 2003, 20. I have no idea what Chinese public opinion thinks about this trade.

${ }^{69}$ Today, 11 U.S. cattle producers are certified to raise cattle for eventual beef shipments to Europe. Clayton, above n 62 .
} 
United States. If Europe were to impose an emissions tax on U.S. imports, and it does not induce U.S. cooperation, then the tax will not accomplish anything for Europe toward satisfying its preferences of preventing climate change. Unlike the dog fur ban, where Lamy's safeguard would allow the United States to continue excluding the fur, for climate change, the safeguard would not offer any benefit to Europe if it has to compensate U.S. exporters for the emissions tax. The same obstacle exists for other issues where collective preferences need to be translated into international collective action, for example, fishery conservation or the prevention of nuclear proliferation. This category of issues is characterized by substantial transborder physical externalities and is sometimes referred to as 'global public goods'. The usefulness of the collective preference safeguard for global public goods seems doubtful.

Would the collective preference safeguard be more justifiable for inwardly-directed than outwardly-directed measures? Arguably so, yet one also has to consider an issue not addressed much in Lamy's paper-that is, whether WTO rules leave enough discretion for domestic measures. Lamy seems to think that the rules do. He states that the WTO Appellate Body 'has been a faithful guardian of "collective preferences" under the WTO system'. ${ }^{70}$ This view is echoed by the WTO Secretariat which asserts on the WTO website that 'Compliance with WTO Agreements does not in any way reduce the right of a government to make laws for its own territories' ${ }^{71}$ In my view, such assurances may not be justified. As WTO disciplines get interpreted more stringently, the need for a collective preference safeguard would increase. Part V looks at this issue.

\section{SUPERVISION OF DOMESTIC POLICY BY WTO RULES}

\footnotetext{
${ }^{70}$ Above $n$ 1, at 7.

${ }^{71}$ WTO Secretariat, 'WTO Policy Issues for Parliamentarians', 2001, at 11, http://www.wto.org/english/thewto_e/whatis_e/whatis_e.htm (visited 19 December 2004).
} 
WTO rules govern not only trade measures but also many domestic measures that may have implications for trade. The supervision of domestic policy is the most controversial feature of WTO law. Table 1 below shows many of the ways in which WTO rules can potentially prevent nonprotectionist domestic measures designed to achieve collective preferences. The intent in Table 1 is to consider only inwardly-directed preferences. In a few instances, footnotes are added where the entry may be obscure. 
Table 1. Supervision of Collective Preferences By WTO Agreements

\begin{tabular}{|l|l|}
\hline \multicolumn{1}{|c|}{ Collective Preference } & \multicolumn{1}{c|}{ Key Governing WTO Provisions } \\
\hline Grants to Domestic Producers & $\begin{array}{l}\text { Agreement on Agriculture, SCM Agreement }{ }^{72}, \\
\text { Anti-Dumping Agreement }{ }^{33}\end{array}$ \\
\hline Taxes on Domestic Persons and Products & SCM Agreement \\
\hline Taxes on Foreign Persons and Imports & GATT, GATS \\
\hline Regulations on Imported Products/Services & GATT, GATS, SPS Agreement, TBT Agreement \\
\hline Regulation of Criminal Activity & $\begin{array}{l}\text { Antidumping Agreement } \\
\text { Agreement }\end{array}$ \\
\hline Informational/Labeling Requirements & TBT Agreement \\
\hline Stewardship of Global Commons & \\
\hline Delineation of Ownership & $\begin{array}{l}\text { GATT, GATS, TBT Agreement, TRIPS } \\
\text { Agreement }\end{array}$ \\
\hline
\end{tabular}

Whether these rules actually do infringe on legitimate domestic measures will depend on how they are adjudicated by WTO panels and the Appellate Body. Without suggesting here that any of this jurisprudence was wrongly decided, let me briefly note several WTO decisions that have implications for the fulfillment of domestic autonomy. In United States - Anti-Dumping Act of 1916,

\footnotetext{
${ }^{72}$ Today, the SCM Agreement is less deferential to domestic autonomy than it was in 1995. Article 8 of the SCM Agreement identified certain subsidies that were to be non-actionable. These domestic subsidies were designed either to correct market failures or to promote redistributional objectives. Unfortunately, WTO Members allowed this provision to expire in 2000.

${ }^{73}$ For example, Anti-Dumping Agreement, Article 18.1.

${ }^{74}$ Ibid.
}

${ }^{75}$ Stewardship of the global commons is not solely externally-directed because every nation shares in the commons. 
a longtime U.S. antitrust law was found to violate the Anti-Dumping Agreement. ${ }^{76}$ In United States Continued Dumping and Offset Subsidy Act of 2000 (known as the Byrd Amendment case), a cash payment to injured producers was found to violate the GATT and the Antidumping and SCM Agreements. ${ }^{77}$ In Australia - Measures Affecting Importation of Salmon, a sanitary control restricting ocean-caught Pacific salmon was found to violate the Agreement on the Application of Sanitary and Phytosanitary Measures (SPS). ${ }^{78}$ The specific violation was that the government's chosen level of protection against pathogenic salmon risks was inconsistent with its chosen protection against risks from comparable products (namely herring, cod, haddock, eel, finfish, and other Canadian salmon) and the distinctions being made by Australia were arbitrary or unjustifiable and were perceived by the panel to result in a 'disguised restriction on international trade' ${ }^{79}$ In European Communities Sardines, a European food labeling regulation was found to violate the Agreement on Technical Barriers to Trade (TBT) because the regulation was not based on a relevant international standard. ${ }^{80}$ The Communities lost the case notwithstanding its argument that the international standard was an ineffective or inappropriate means for fulfilling the European regulatory objective. ${ }^{81}$

\footnotetext{
${ }^{76}$ WTO Appellate Body Report, United States - Anti-Dumping Act of 1916, WT/DS136,162/AB/R, adopted 26 September 2000. For critical commentary, see Mitsui Matsushita and Douglas E. Rosenthal, 'Was the WTO Mistaken in Ruling on Antidumping Act of 1916?', BNA International Trade Reporter, 13 September 2001, 1450.

${ }^{77}$ WTO Appellate Body Report, United States - Continued Dumping and Subsidy Offset Act of 2000, WT/DS217,234/AB/R, adopted 23 January 2003. For critical commentary, see John Greenwald, 'WTO Dispute Settlement: An Exercise in Trade Law Legislation', 6 JIEL 113 (2003), at 120-23.

${ }^{78}$ WTO Appellate Body Report, Australia - Measures Affecting Importation of Salmon, WT/DS18/AB/R, adopted 6 November 1998.

${ }^{79}$ Ibid, paras. 139-78, 227-40.

${ }^{80}$ WTO Appellate Body Report, European Communities - Trade Description of Sardines, WT/DS231/AB/R, adopted 23 October 2002.

${ }^{81}$ Ibid, para. 291. The ruling occurred even though neither the complaining country Peru nor any of the governments in the Communities had accepted the international standard approved without consensus in the Codex Alimentarius Commission.
} 
The trumping of domestic social objectives by WTO rules can also be seen in the decisions on public policy exceptions where these provisions have been interpreted stringently. One biting aspect of this jurisprudence is the use of a 'weighing and balancing' analysis in which three factors-(1) the contribution of the disputed measure to the country employing it, (2) the 'importance' of the 'common interests or values' protected by the measure, and (3) the impact of the measure on tradeare weighed against each other. ${ }^{82}$ The weighing occurs in the context of determining whether the importing country's measure is 'necessary'. In European Communities - Conditions for the Granting of Tariff Preferences, the 'weighing and balancing' technique was extended to determine whether the purported health measure was cognizable as a health measure under GATT Article XX(b). ${ }^{83}$ The panel weighed the health benefits of the measure to Europe against what the panel perceived as the 'damage of the measure to the multilateral negotiating framework', and then decided that this alleged damage was enough for it to refuse to accept the narcotics control effort as a health measure. ${ }^{84}$ In my view, when the availability of the GATT's public policy exceptions hinges on the commercial impact of the measure on other countries, the WTO dispute system will be engaging in inter-country comparisons of utility. Such judgments will be hard to make in a principled and predictable fashion. For example, the Appellate Body has not yet explained how it measures the 'importance' of a

\footnotetext{
${ }^{82}$ WTO Appellate Body Report, Korea - Measures Affecting Imports of Fresh, Chilled and Frozen Beef, WT/DS161,169/AB/R, adopted 10 January 2001, paras. 163-64; applied to health measures in WTO Appellate Body Report, European Communities - Measures Affecting Asbestos and AsbestosContaining Products, WT/DS135/AB/R, adopted 5 April 2001, para. 172. The Appellate Body did not explain how the weighing is to occur. Sarah Cleveland has proposed a mathematical equation for the Appellate Body's proportionality test. See Sarah H. Cleveland, 'Human Rights Sanctions and International Trade: A Theory of Compatibility’, 5 JIEL 133 (2002), at 169.

${ }^{83}$ WTO Panel Report, European Communities - Conditions for the Granting of Tariff Preferences to Developing Countries, WT/DS246/R, adopted as modified by the Appellate Body 20 April 2004, paras. 7.209-7.210.

${ }^{84}$ Ibid.
} 
national 'value'. ${ }^{85}$ In European Communities - Tariff Preferences, the panel did not explain how one determines when national actions damage the multilateral trading system.

In the first 'General Exceptions' case adjudicated under the GATS, the panel held that for a measure to be 'necessary' under the moral exception in GATS Article XIV(a), the United States was required to negotiate with Antigua to see if a way could be found to avoid the harm associated with the internet gambling services that Antigua's private sector was offering to U.S. residents. ${ }^{86}$ The fact that the United States had not entered into negotiations was a key reason why it lost the case at the panel level. The panel went so far as to say that U.S. negotiation with Antigua was required even if the United States considered the gambling ban 'indispensable'. ${ }^{87}$ Note that the panel did not suggest that seeking to negotiate was a principle of international law that serves a backdrop to the GATS. ${ }^{88}$ Instead, the panel discovered the requirement to negotiate by employing the Appellate Body's 'weighing and balancing' test. ${ }^{89}$ As has often happened in GATT/WTO jurisprudence of public policy exceptions, panels seem eager to add substantive and procedural hurdles not present in the treaty text.

\footnotetext{
${ }^{85}$ Korea - Beef, above n 82, para. 164. For example, does a Lamy-style collective preference have greater importance than a regulation drawn up by bureaucrats?

${ }^{86}$ WTO Panel Report, United States - Measures Affecting the Cross-Border Supply of Gambling and Betting Services, WT/DS285/R, circulated 10 November 2004, paras. 6.529-6.533. In reaching this conclusion, the panel found relevant a similar holding given in the panel decision in the first tunadolphin case. Ibid para. 6.526 and n. 980 (recalling the Appellate Body's dictum that panels might find unadopted GATT panel reports to offer useful guidance). In my view, any time a WTO panel follows the reasoning of the unadopted 1991 and 1994 tuna-dolphin reports, the results will prove as mischievous for the WTO as they did for the GATT.

${ }^{87}$ United States - Gambling, above n 86, para. 6.534 (suggesting that for a state's trade measure to be 'necessary' under GATT Article XX, the state should first pursue other appropriate measures such as diplomatic overtures or foreign assistance).

${ }^{88}$ Cleveland, above n 82, at 166.

${ }^{89}$ United States - Gambling, above n 86, para. 6.477.
} 
In taking note of this jurisprudence, I do not mean to suggest that no national collective preference is safe at the WTO. My point only is that the evolution of the jurisprudence on public policy exceptions should be a central factor in considering whether a new safeguard is needed. In contending that WTO dispute system 'has been a faithful guardian' of collective preferences, Lamy's paper skips over important legal and factual questions. In my view, such a safeguard will become more urgent if trends continue in the WTO to denigrate the exceptions. Let me reiterate that my analysis focuses on inwardly-directed preferences. The WTO jurisprudence on outwardly-directed preferences is another matter.

Perhaps Lamy’s view on guardianship is colored by a misunderstanding. For example, he sees the Appellate Body decision in United States - Shrimp as 'departing' from a 'strict jurisdictional reading' of GATT Article XX(g), and his paper seems to favor that broader geographic scope. ${ }^{90}$ In fact, however, the Appellate Body did not make that departure. ${ }^{91}$

\section{CONCLUSION}

In an interconnected world, value-free trade is a fiction. Individuals, groups, and governments are sure to have preferences about international commerce that will complicate voluntary transactions between buyer and seller. Recognizing this difficulty, Lamy wants the WTO to experiment with a new safeguard for collective preferences that violate WTO rules. Lamy is trying to safeguard democratic choices at the national level from being overridden in the WTO. Equally important, he is trying to safeguard the WTO from a free market zeal that could undermine public support for the trading system. Lamy's purpose is apposite in my view.

\footnotetext{
${ }^{90}$ Above n 1, at 7.

${ }^{91}$ See WTO Appellate Body Report, United States - Import Prohibition of Certain Shrimp and Shrimp Products, WT/DS58/AB/R, adopted 6 November 1998, para. 133; W.J. Davey, 'WTO Dispute Settlement Practice Relating to GATT 1994', in Federico Ortino and Ernst-Ulrich Petersmann (eds), The WTO Dispute Settlement System 1995-2003 (The Hague: Kluwer Law International 2004) 191, 205.
} 
Nevertheless, I doubt the political practicality of adding a new safeguard to the WTO. The problem is that many governments would oppose the idea and demand a high front-end payment for accepting it even though each recourse to the safeguard entails a compensatory payment Thus, I predict a continuation of the status quo in which powerful governments retain WTO-illegal collective preferences and suffer any ensuing SCOO.

Lamy's attention to the process of domestic validation has independent merit. Governments exposed to pressures for unwise collective preferences can do a better job engaging in deliberation and promoting public education. Expecting politicians to exhibit that kind of leadership may be utopian. 